\title{
Sex Steroid Influence on Triglyceride Metabolism
}

\author{
HaK-Joong Kim and Ronald K. Kalkhoff \\ From the Endocrine-Metabolic Section, Division of Medicine, Medical College \\ of Wisconsin, Milwaukee, Wisconsin 53226
}

A B S T R A C T Triglyceride metabolism was investigated in groups of fed and fasted rats after 21 days of parenteral estradiol (5 $\mathrm{mg}$ daily), progesterone $(5 \mathrm{mg}$ daily), or the two steroids in combination. Results were compared with control groups receiving an oil solvent alone. In rats given estradiol separately or combined with progesterone, hypertriglyceridemia was uniformly associated with increased plasma triglyceride entry, estimated with the i.v. Triton WR1339 technique. Progesterone alone had no effect on these parameters.

Plasma postheparin lipolytic activity (PHLA), adipose, mammary gland, and protamine-resistant lipoprotein lipases (LPL) were significantly increased in progesterone-treated rats and significantly decreased in rats receiving estradiol with the exception of mammary gland LPL, which was also increased to a slight extent. The combined regimen reduced plasma PHLA and increased protamine-resistant, adipose, and mammary gland LPL activity.

Sex steroid treatments had minimal effects on plasma glucose and free fatty acid concentrations, but all increased plasma insulin significantly. Hyperinsulinemia did not parallel changes in body weight or other measured parameters. Linear regression analyses revealed that plasma triglyceride concentrations in all fed, treated rats correlated significantly with triglyceride entry but not very uniformly with plasma or tissue LPL activity.

We conclude that estradiol, unlike progesterone, has substantial lipemic effects in the rat which relate best to triglyceride entry. Hyperinsulinemia, changes in body weight, plasma PHLA, and tissue LPL activities did not consistently predict the influence of sex steroid treatment on plasma triglyceride concentrations.

\section{INTRODUCTION}

Estrogens induce elevated plasma triglycerides $(1,2)$ and undoubtedly have a role in the development of

Presented in part at the 46th Annual Meeting of the Central Society for Clinical Research, 2 November 1973, Chicago, Ill.

Received for publication 12 August 1974 and in revised form 2 May 1975. hyperlipemia observed during advancing pregnancy or after the administration of oral contraceptive agents $(3,4)$. However, some progestins lower plasma triglycerides and have been utilized in the treatment of certain lipid disorders (5).

The means by which these steroid hormones influence triglyceride metabolism are not well defined. Estrogeninduced hyperlipemia was thought to reside in impaired peripheral tissue removal of triglyceride, a conclusion based on the suppressive effects of natural and synthetic estrogens on plasma postheparin lipolytic activity, PHLA $(6,7) .{ }^{1}$ More recent studies suggest that peripheral removal is actually normal in these instances $(8,9)$. Although the lowering of serum triglyceride by progestin treatment correlates with increased PHLA (5), more precise events responsible for these effects are also unknown.

Other in vitro investigations that have focused attention on hepatic synthesis and release of lipid into the circulation also do not resolve the problem. After estrogen treatment, precursor incorporation into hepatic triglycerides has been shown to be normal (10), decreased (11), or increased (12). Oral contraceptive agents and other combinations of estrogen and progesterone appear to increase hepatic turnover of this lipid $(13,14)$.

In the present study female virgin rats were exposed to physiologic doses of estradiol and progesterone singly or in combination, for 21 days, a normal rat gestation period. Effects of these regimens on triglyceride entry were compared to their action on plasma PHLA, adipose, mammary gland, and protamine-resistant lipoprotein lipase (LPL). These data, in turn, were correlated with alterations of other plasma substrates and insulin concentrations.

The results of our investigation suggest that triglyceride entry into the plasma compartment is an important determinant of plasma triglyceride alterations after sex steroid administration.

${ }^{1}$ Abbreviations used in this paper: PHLA, postheparin lipolytic activity; LPL, lipoprotein lipase; TG, triglyceride; $\mathrm{E}$, estradiol; $\mathrm{P}$, progesterone; $\mathrm{E}+\mathrm{P}$, estradiol plus progesterone; apo-VLDL, apo-very low density lipoprotein. 


\section{METHODS}

Preparation of animals. Female Sprague-Dawley rats weighing 220-230 g were fed Purina Rat Chow ad lib. (Ralston Purina Co., St. Louis, Mo.) and housed in quarters with controlled temperature $\left(24^{\circ} \mathrm{C}\right)$ and light $(6$ a.m.6 p.m.). Animals were subdivided into four groups. Control rats received intramuscular sesame oil alone for 21 days. A second group received estradiol benzoate $(E)$ in oil, $5 \mu \mathrm{g}$ daily for the same period. The third group was given progesterone $(\mathrm{P})$ in oil, $5 \mathrm{mg}$ daily for 21 days. The fourth group was on a combined regimen $(E+P)$, $5 \mu \mathrm{g}$ and $5 \mathrm{mg}$ of the two hormones, respectively, during the 3-wk period. One-half of the total dose was injected twice daily; injection sites were rotated and volumes of injection did not exceed $0.2 \mathrm{ml}$.

On the 22nd day, certain groups were studied after $2 \mathrm{~h}$ of fasting (hereafter, considered the "fed" animals). Other groups were studied after a 12 -h fast. Water was not withheld.

Triglyceride entry studies and measurements of plasma Triton. Triglyceride entry into the plasma compartment was estimated according to an established method (15). Rats were placed under light ether anesthesia. Triton

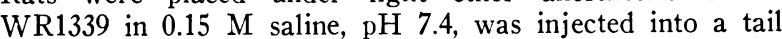
vein in a dosage of $40 \mathrm{mg} / 100 \mathrm{~g}$ body weight. Blood samples were obtained from the retroorbital plexus before $(0 \mathrm{~min})$ and $90 \mathrm{~min}$ after injection. Plasma Triton concentrations were measured in 0 - and $90-\mathrm{min}$ samples according to a published method (16). The extraction procedure was modified by increasing the relative amount of isopropranol ( $100 \mathrm{vol} / \mathrm{vol}$ of serum).

At $90 \mathrm{~min}, 0.5 \mu \mathrm{Ci}$ of ${ }^{125} \mathrm{I}$-albumin ${ }^{2}$ was injected intravenously and after 5 and $10 \mathrm{~min}$, additional $0.5-\mathrm{ml}$ blood samples were obtained. Duplicate plasma samples $(100 \mu \mathrm{l})$ were counted in a Packard autogamma spectrometer (Packard Instrument Co., Inc., Downers Grove, I11.) The total counts per minute at 5 - and $10-\mathrm{min}$ intervals were plotted on semilogarithmic graph paper, and 0 -min counts were extrapolated. Plasma volumes were calculated from the following equations (17):

Plasma volume $(\mathrm{ml})$

$$
=\frac{\mathrm{cpm} / 100 \mu \mathrm{l} \text { of injected }{ }^{125} \mathrm{I} \text {-albumin }}{\mathrm{cpm} / 100 \mu \mathrm{l} \text { of plasma at } 0 \mathrm{~min}}
$$

$\times$ dilution factor.

Knowing plasma volume triglyceride (TG) entry is estimated by the equation below: ${ }^{3}$

TG entry $(\mu \mathrm{mol} / 90 \mathrm{~min})=$

plasma volume $(\mathrm{ml}) \times(90 \mathrm{~min} \mathrm{TG}$ plasma concentration increment $[\mu \mathrm{mol} / \mathrm{ml}])$.

Preparation of postheparin plasma. Blood samples were obtained from the retroorbital plexus of fed animals under light ether anesthesia at $0 \mathrm{~min}$. $250 \mathrm{IU}$ of heparin $/ \mathrm{kg}$ body weight was then injected into the tail vein, and a second blood sample was withdrawn from the abdominal aorta

\footnotetext{
${ }^{2}$ In preliminary, unpublished studies, radioiodinated albumin was shown to have initial decay curves similar to labeled rat albumin when injected into rats.

${ }^{3}$ The calculation of TG entry rate is an approximation, since the Triton inhibition of peripheral tissue TG uptake is $85-90 \%$ complete (15).
}

10 min later, the time at which average peak PHLA activity was observed (see Results). Blood was placed in chilled tubes containing 2 IU of heparin $/ \mathrm{ml}$ blood. Plasma was separated by centrifugation at $4^{\circ} \mathrm{C}$ and frozen at $-20^{\circ} \mathrm{C}$.

On the day of assay for plasma PHLA, $50 \mu 1$ of preand postheparin plasma was preincubated simultaneously for $10 \mathrm{~min}$ at $27^{\circ} \mathrm{C}$ with an equal volume of $0.05 \mathrm{M}$ $\mathrm{NH}_{4} \mathrm{OH}-\mathrm{NH}_{4} \mathrm{Cl}$ buffer, $\mathrm{pH}$ 8.4. The control preincubations were performed in triplicate and compared to a second triplicate system containing protamine sulfate $(7.5 \mathrm{mg} / \mathrm{ml}$ buffer).

Preparation of adipose tissue and mammary glands. Fed rats were decapitated and parametrial fat and inguinal-abdominal mammary glands were excised. After washing three times with $0.15 \mathrm{M}$ saline at $4^{\circ} \mathrm{C}$, the tissues were blotted free of excess saline and quickly weighed. Tissues were homogenized in a Waring blendor (Waring Products Div., New Hartford, Conn.) containing 50 vol of acetone at $4^{\circ} \mathrm{C}$ for $1 \mathrm{~min}$. Adipose tissue homogenates were filtered through Whatman no. 5 paper on a Büchner funnel. Residues on filter paper were washed three times with 50 $\mathrm{ml}$ cold acetone and three times with $50 \mathrm{ml}$ of anhydrous diethyl ether (18). Residues were then placed in a desiccator jar and traces of ether removed by vacuum suction. Dried residues were stored at $4^{\circ} \mathrm{C}$ in racuo, and lipase activity was measured within 2 wk. With this method of storage some loss of enzyme activity (up to $10 \%$ ) is unavoidable. For this reason representative residue from control and treated rats stored for identical durations were always assayed together on the same day.

Mammary gland homogenates obtained from the Waring blendor were treated in a similar fashion $(19,20)$ except that filtering was done with cheesecloth before subsequent filtering with Whatman no. 5 paper. Milk was not removed from glandular tissue.

Preparation of tissue extracts for LPL assay. Tissue powder was homogenized in $0.05 \mathrm{M} \mathrm{NH}{ }_{4} \mathrm{OH}-\mathrm{NH}_{4} \mathrm{Cl}$ buffer, $\mathrm{pH} 8.4$ containing $1 \mathrm{IU}$ of heparin $/ \mathrm{ml}$. Known weights of adipose tissue powder $(5 \mathrm{mg} / \mathrm{ml})$ or mammary gland powder $(10 \mathrm{mg} / \mathrm{ml})$ were homogenized with a motor-driven Teflon pestle inserted into a Potter-Elvehjem glass homogenizer at $4^{\circ} \mathrm{C}$ for $2 \mathrm{~min}$.

After standing $60 \mathrm{~min}$ in the cold, homogenates were centrifuged for $10 \mathrm{~min}$ at $2,000 \mathrm{rpm}$ at $4^{\circ} \mathrm{C}$. Supernates were withdrawn for LPL assay and for measurements of protein content (21). Additional aliquots of both supernate and precipitate were taken for determinations of DNA (22).

Preparation of artificial lipid emulsion. Pyrex glass tubes $(1.8 \times 10 \mathrm{~cm})$ were placed in an ice bath at $0^{\circ} \mathrm{C} .270$ $\mathrm{mg}$ of triolein, $20 \mu \mathrm{Ci}$ of $\left[2{ }^{3} \mathrm{H}\right]$ glyceryl trioleate, $16.2 \mathrm{mg}$ of egg lecithin, $2.0 \mathrm{ml}$ of $10 \%$ albumin (fatty acid poor) in ammonium buffer at $\mathrm{pH} 8.0,1.6 \mathrm{ml}$ of $2 \mathrm{M}$ Tris- $\mathrm{HCl}$ buffer, $\mathrm{pH} 8.4$, and $1.4 \mathrm{ml}$ of water were added to the tubes (23). These were sonicated in a Branson Sonifier (model LS 185C, Heat Systems-Ultrasonics, Inc., Plainview, N. Y.), tuned to $60 \mathrm{~W} / \mathrm{s}$. 1-min sonication periods were followed by a 1-min pause and repeated two additional times.

The emulsion was activated by the addition of $12.0 \mathrm{ml}$ of apo-very low density lipoprotein (apo-VLDL), $250 \mathrm{mg}$ of apo-VLDL protein/ml of ammonium bicarbonate buffer, $\mathrm{pH} 8.6$, for $30 \mathrm{~min}$ at $37^{\circ} \mathrm{C}$. The apo-VLDL was prepared from plasma obtained from a patient with type I (Fredrickson) hyperlipoproteinemia. Techniques for preparation are outlined elsewhere (24-26). 
TABLE I

Plasma Substrate and Insulin Concentrations in Fed and Fasted Animals

\begin{tabular}{lcccc}
\hline & \multicolumn{4}{c}{ Animal group* } \\
\cline { 2 - 5 } & $\mathrm{C}$ & $\mathrm{E}$ & $\mathrm{P}$ & $\mathrm{E}+\mathrm{P}$ \\
\hline Glucose, $m g / 100 \mathrm{ml}$ & $141 \pm 8$ & $146 \pm 7$ & $136 \pm 6$ & $138 \pm 6$ \\
& $(118 \pm 4)$ & $(125 \pm 6)$ & $(115 \pm 3)$ & $(120 \pm 6)$ \\
Free fatty acids, $\mu$ eq/liter & $194 \pm 8$ & $258 \pm 30$ & $172 \pm 24$ & $241 \pm 31$ \\
& $(529 \pm 30)$ & $(612 \pm 55) \ddagger$ & $(580 \pm 42)$ & $(598 \pm 48)$ \\
Insulin, $\mu U / m l$ & $26 \pm 4$ & $35 \pm 4 \ddagger$ & $35 \pm 4 \ddagger$ & $42 \pm 6 \ddagger$ \\
& $(11 \pm 1)$ & $(30 \pm 4) \ddagger$ & $(27 \pm 5) \ddagger$ & $(21 \pm 3) \ddagger$ \\
TG, $\mu \mathrm{mol} / \mathrm{ml}$ & $1.6 \pm 0.21$ & $3.23 \pm 0.6 \ddagger$ & $1.5 \pm 0.17 \S$ & $2.57 \pm 0.21 \ddagger \|$ \\
& $(1.16 \pm 0.11)$ & $(2.32 \pm 0.23) \ddagger$ & $(1.22 \pm 0.13)$ & $(2.34 \pm 0.27)^{*}$ \\
Percent weight gain & $19 \pm 2$ & $12 \pm 2 \ddagger$ & $31 \pm 1 \ddagger \S$ & $24 \pm 3 \S \|$ \\
& $(7 \pm 1)$ & $(9 \pm 2)$ & $(17 \pm 1) \ddagger$ & $(12 \pm 1) \ddagger$ \\
\hline
\end{tabular}

* There were 15 animals in each fed group and 25 animals in each fasted group. Values for fasted animals are in parentheses.

$\ddagger \S \|$ Significance of the difference between corresponding group means \pm SEM : ( $\ddagger$ ) control (C) vs. other group, $P<0.05$; (\$) E vs. $\mathrm{P}$ or $\mathrm{E}+\mathrm{P}, P<0.05$; (\|) $\mathrm{P}$ vs. $\mathrm{E}+\mathrm{P}, P<0.05$.

PHLA and tissue LPL assays. Activated lipid emulsion $(0.6 \mathrm{ml})$ was added to preincubated plasma samples or to $0.2-0.4 \mathrm{ml}$ of mammary gland or adipose tissue extracts (see previous sections). Final volume was adjusted to 1.0 $\mathrm{ml}$ with $0.05 \mathrm{M}$ ammonium buffer.

Tubes were placed in a Dubnoff metabolic shaker and incubated for $60 \mathrm{~min}$ at $37^{\circ} \mathrm{C}$. The reaction was terminated by the addition of $1.0 \mathrm{ml}$ of $10 \%$ trichloroacetic acid (wt/ vol). Vigorous mixing was followed by cold centrifugation for $10 \mathrm{~min}$ at $2,000 \mathrm{rpm}$. $1.0-\mathrm{ml}$ supernates containing newly formed $\left[{ }^{3} \mathrm{H}\right]$ glycerol were mixed with a scintillation liquid and counted (23).

PHLA activity was expressed as $\mu \mathrm{mol}$ glycerol released/ $\mathrm{ml}$ plasma per $60 \mathrm{~min}$. Tissue LPL activity was recorded as nmols glycerol released per $\mathrm{g}$ wet weight, per $\mathrm{mg}$ tissue protein, or per $\mu \mathrm{g}$ DNA in $60 \mathrm{~min}$.

Plasma substrate and hormone measurements. Plasma glucose concentrations were determined by a glucose oxidase method. Measurements of plasma free fatty acids, TG, and insulin were performed by techniques previously published (27-29).

Statistical analyses. Comparison of mean values of one group of rats to corresponding values of another was performed by applying Student's $t$ test to unpaired data, and correlation coefficients were calculated by linear regression analysis (30).

Commercial sources of chemicals. $\left[2-{ }^{3} \mathrm{H}\right] \mathrm{Glyceryl}$ trioleate was obtained from Amersham/Searle Corp., Arlington Heights, Ill. Egg lecithin, triolein, $\beta$-estradiol-3-benzoate, and progesterone were purchased from Sigma Chemical Co., St. Louis, Mo. Bovine serum albumin, fatty acid poor, was obtained from Miles Laboratories, Inc., Elkhart, Ind. Radioiodinated albumin and Triton WR-1339 were purchased from Mallinckrodt Chemical Works, St. Louis, Mo., and Rohm and Haas Co., Philadelphia, Pa., respectively.

\section{RESULTS}

Changes in plasma substrate and insulin concentrations. $3 \mathrm{wk}$ of treatment with $\mathrm{E}$ and $\mathrm{P}$, separately or in combination, had no significant effects on plasma glucose or free fatty acid concentrations in fed animals. Similar results were observed in fasted animals except in the $\mathrm{E}$ group whose free fatty acid concentrations were slightly increased. Insulin concentrations were significantly increased by all treatment regimens ( $\mathrm{Ta}$ ble I).

$\mathrm{E}$ alone or in combination with $\mathrm{P}$ elevated plasma TG levels, whereas $P$ by itself did not alter this parameter. Regimens containing $\mathrm{P}$ promoted a greater weight gain over the 3 -wk period in contrast to $\mathrm{E}$ alone, which resulted in decreased weight gain in fed rats and normal weight gain in fasted rats as compared to the control group. Fasted animals had lower basal glucose, insulin, and TG concentrations and higher FFA levels than did the fed group (Table I).

Relationship between Triton dosage and TG increment. At an intravenous dosage of $40 \mathrm{mg}$ Triton/100 g body weight, net plasma increments of Triton at $90 \mathrm{~min}$ were not significantly different among the four groups of animals (Table II). Dosages of 30, 40, 50, and 60 $\mathrm{mg} / 100 \mathrm{~g}$ body weight resulted in progressively higher 90-min Triton plasma increments. However, 90-min plasma TG increments for a given group of animals were not different in this dosage range. These latter observations are similar to those reported previously (31). Therefore, the $40-\mathrm{mg} / 100 \mathrm{~g}$ dose of Triton used in this study appeared to be adequate for inducing optimum effects on peripheral TG uptake.

$T G$ entry into plasma. E alone or in combination with $\mathrm{P}$ significantly increased the mean increment of plasma TG and TG entry $90 \mathrm{~min}$ after Triton injection. 
TABLE II

T(i Entry into Plasma after Triton Injection in Fed and Fasted Animals

\begin{tabular}{|c|c|c|c|c|}
\hline \multirow[b]{2}{*}{ Parameter* } & \multicolumn{4}{|c|}{ Animal group } \\
\hline & $\mathrm{C}$ & $\mathrm{E}$ & $\mathbf{P}$ & $\mathrm{E}+\mathrm{P}$ \\
\hline Final body weight, s & $\begin{array}{c}257 \pm 2.6 \\
(260 \pm 3.7)\end{array}$ & $\begin{array}{c}260 \pm 4.2 \\
(260 \pm 4.8)\end{array}$ & $\begin{array}{c}283 \pm 4.2+\S \\
(284 \pm 3.1) \neq \S\end{array}$ & $\begin{array}{c}276 \pm 4.4 \pm \S \\
(278 \pm 2.7) \ddagger \S\end{array}$ \\
\hline Plasma volume, $m l$ & $\begin{array}{c}8.7 \pm 0.3 \\
(9.2 \pm 0.3)\end{array}$ & $\begin{array}{c}8.7 \pm 0.2 \\
(10.1 \pm 0.3) \ddagger\end{array}$ & $\begin{array}{r}9.86 \pm 0.3 \ddagger \S \\
(10.5 \pm 0.3) \ddagger\end{array}$ & $\begin{array}{c}9.3 \pm 0.2 \S \\
(10.3 \pm 0.2) \ddagger\end{array}$ \\
\hline $0 \mathrm{~min}$ plasma TG concentration, $\mu \mathrm{mol} / \mathrm{ml}$ & $\begin{array}{c}1.60 \pm 0.21 \\
(1.16 \pm 0.11)\end{array}$ & $\begin{array}{c}3.23 \pm 0.6 \ddagger \\
(2.32 \pm 0.23) \ddagger\end{array}$ & $\begin{array}{c}1.5 \pm 0.17 \S \\
(1.22 \pm 0.13) \S\end{array}$ & $\begin{array}{c}2.57 \pm 0.21 \ddagger \| \\
(2.34 \pm 0.27) \ddagger \|\end{array}$ \\
\hline $90 \mathrm{~min}$ plasma TG increment, $\mu \mathrm{mol} / \mathrm{ml} / 90 \mathrm{~min}$ & $\begin{array}{c}9.3 \pm 0.4 \\
(6.2 \pm 0.3)\end{array}$ & $\begin{array}{c}15.7 \pm 0.6 \ddagger \\
(8.7 \pm 0.6) \ddagger\end{array}$ & $\begin{array}{c}8.4 \pm 0.8 \S \\
(6.9 \pm 0.5) \S\end{array}$ & $\begin{array}{c}12.2 \pm 0.7 \ddagger \S \| \\
(9.5 \pm 0.5) \ddagger \|\end{array}$ \\
\hline TG entry, $\mu \mathrm{mol} / 90 \mathrm{~min}$ & $\begin{array}{c}80.7 \pm 4.4 \\
(60.3 \pm 4.8)\end{array}$ & $\begin{array}{c}137.4 \pm 7.7 \ddagger \\
(83.2 \pm 7.3) \ddagger\end{array}$ & $\begin{array}{c}80.5 \pm 7.3 \S \\
(72.0 \pm 5.2)\end{array}$ & $\begin{array}{l}112.6 \pm 5.5 \ddagger \S \| \\
(94.0 \pm 6.7) \ddagger \|\end{array}$ \\
\hline 90 min plasma Triton increment, $\mathrm{mg} / \mathrm{ml}$ & $\begin{array}{c}5.5 \pm 0.1 \\
(5.3 \pm 0.6)\end{array}$ & $\begin{array}{c}5.6 \pm 0.2 \\
(5.5 \pm 0.5)\end{array}$ & $\begin{array}{c}5.6 \pm 0.1 \\
(4.9 \pm 0.8)\end{array}$ & $\begin{array}{c}5.8 \pm 0.4 \\
(5.0 \pm 0.7)\end{array}$ \\
\hline
\end{tabular}

* 10 animals were in each fed group, and 25 animals were in each fasted group. Values of fasted animals are in parentheses. $\$ \$$ Significance of the difference between corresponding group means \pm SEM : ( $\ddagger$ ) control $(\mathrm{C})$ vs. other groups, $P<0.05$; (§) E vs. $\mathrm{P}$ or $\mathrm{E}+\mathrm{P}, P<0.05$; (\|) $\mathrm{P}$ vs. $\mathrm{E}+\mathrm{P}, P<0.05$.

$\mathrm{P}$ treatment, however, produced changes that did not differ from control values (Table II).

Plasma PHLA. $25 \mathrm{IU}$ of heparin/100 g body weight injected i.v. induced peak PHLA activity within $10 \mathrm{~min}$. This observation was based on a study of 44 rats and measurements of PHLA at several different intervals after heparin administration (Fig. 1). ${ }^{4}$

PHLA in the absence or presence of protamine additions was depressed to the greatest extent by $\mathrm{E}$ and was slightly, though significantly diminished by the combined regimen. $\mathrm{P}$ had the opposite effect and increased PHLA approximately $11 \%$ (Table III).

Protamine additions had significant inhibitory effects on PHLA, and $\mathrm{E}$ or $\mathrm{P}$ alone, respectively decreased and increased lipolytic activity relative to control values. However, the combined regimen in this instance was associated with lipolytic activity that was higher than control means unlike that observed in the absence of protamine. ${ }^{5}$

${ }^{4}$ This dose of heparin is relatively large. It was chosen, because another laboratory has shown recently that PHLA in plasma of rats treated in this way is more stable during subsequent in vitro preincubations. Lower doses of heparin, however, (10 IU/100 $\mathrm{g}$ body weight) induced plasma PHLA that was unstable and substantially reduced in activity during ensuing preincubations (32).

${ }^{5}$ It should be pointed out that protamine, when added to this in vitro system, suppresses extrahepatic LPL more than $90 \%$. Hepatic LPL, however, is depressed only $10 \%$ below total activity (33). Results obtained in the presence of protamine, then reflect mostly hepatic LPI activity.
Mammary gland and adipose tissue LPL. LPL activity in adipose tissue and mammary glands was greatly increased by $\mathrm{P}$ alone or when combined with $\mathrm{E}$. However, the two tissues differed with respect to $E$ treatment. In mammary gland, LPL activity was higher than control values, and the sum of $\mathrm{P}$ - and E-induced changes was approximately equivalent to the LPL activity associated with the combined regimen. In adipose tissue, E suppressed LPL activity unlike the opposite effect of this hormone on the mammary gland. Otherwise, $\mathrm{P}$ and $\mathrm{E}+\mathrm{P}$ had similar effects on LPL activity in both tissues. These relationships applied to data ex-

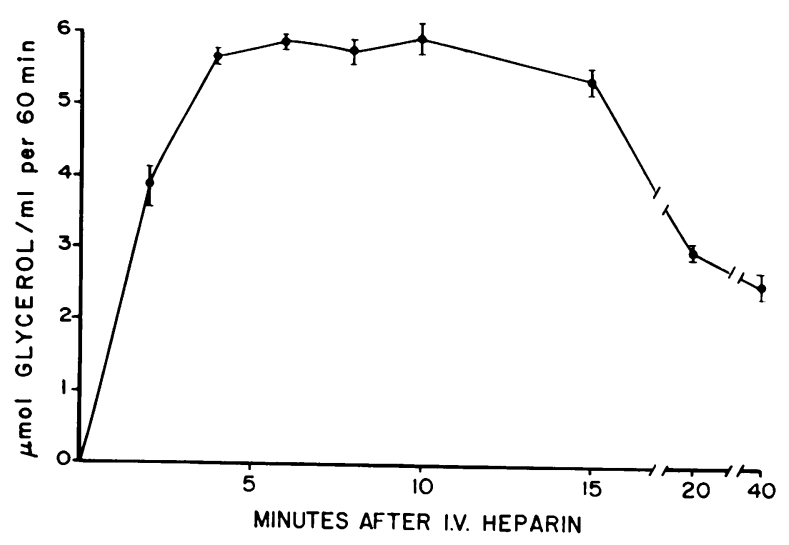

FIGURE 1 Postheparin plasma lipolytic activity in normal female rats at varying intervals after intravenous heparin, $25 \mathrm{IU} / 100 \mathrm{~g}$ body weight. Fach value represents mean \pm SEM for six animals. 
TABLE III

Effects of Sex Steroid Treatment on Rat Plasma PHLA in Fed Animals

\begin{tabular}{|c|c|c|c|c|}
\hline \multirow[b]{2}{*}{ PHLA } & \multicolumn{4}{|c|}{ Animal group* } \\
\hline & $\mathrm{C}$ & $\mathrm{E}$ & $\mathbf{P}$ & $E+P$ \\
\hline Total PHLAł (without protamine) & $5.95 \pm 0.19$ & $4.53 \pm 0.2 \S$ & $6.58 \pm 0.12 \S \|$ & $5.21 \pm 0.13 \S \| \Upsilon$ \\
\hline Protamine-resistant PHLA & $0.66 \pm 0.02^{*}$ & $0.26 \pm 0.2 \S$ & $0.85 \pm 0.03 \S \|$ & $0.84 \pm 0.05 \S \|$ \\
\hline
\end{tabular}

* There were 10 animals in each group.

$\ddagger$ Activities are expressed as micromoles glycerol released per milliliter plasma in 60 min at $37^{\circ} \mathrm{C}$.

$\S \| \uparrow$ Significance of the difference between group means \pm SEM : ( $\S)$ control (C) vs. other groups

$P<0.025$; (\|) E vs. $\mathrm{P}$ or $\mathrm{E}+\mathrm{P}, P<0.025$; ( $(\mathbb{)}) \mathrm{P}$ vs. $\mathrm{E}+\mathrm{P}, P<0.001$.

pressed in terms of lipolytic activity per unit tissue weight, protein, or DNA content (Tables IV, V).

Correlation coefficients relating plasma $T G$ concentrations to TG entry or to lipolytic activity. In fed rats, plasma TG levels related uniformly and most significantly to TG entry. Although inverse correlations were also observed between plasma TG and adipose LPL activity, significance was achieved only in the control group. Relatively poor correlations existed between plasma TG concentrations and plasma PHLA and protamine-resistant PHLA. In the mammary gland, it was of interest that LPL activity tended to parallel concentrations of plasma triglyceride and this was significant after $\mathrm{P}$ administration (Table $\mathrm{VI}$ ).

\section{DISCUSSION}

$\mathrm{E}$ by itself or in combination with $\mathrm{P}$ increases plasma TG in fed and fasted rats. $P$, however, had no significant effect on this parameter. The results are consistent with a number of previous reports of plasma TG alterations after administration of both natural and synthetic estrogens, including those contained in oral contraceptive agents, to animals and human subjects (34).

Since plasma concentrations of this lipid are determined, in part, by rates of entry into the circulation, this investigation focused attention on an index of this event. It is well known that liver synthesis and release of TGcontaining lipoproteins accounts for at least $90 \%$ of circulating TG in the fasting state (35). Our results demonstrate a good relationship between elevated plasma TG concentrations and increased TG entry in both fed and fasted rats exposed to $E$ alone or in combination with $\mathrm{P}$. This suggests that an important action of $\mathrm{E}$ that is responsible for hypertriglyceridemia is increased hepatic release of this lipid.

Augmented TG entry from liver may relate to several metabolic events. Previous studies from this laboratory that employed a similar animal model have shown increased in vitro incorporation of precursors into hepatic $T G$ in animals exposed to $\mathrm{E}+\mathrm{P}$ (10). Additional investigations of a variety of animal species treated with higher, less physiologic doses of estrogens, report similar in vitro results in most, but not all instances (11, 12). More recently, endogenous TG turnover has been shown to be increased in women receiving conventional oral contraceptive agents or synthetic estrogens (13, 14). These reports collectively suggest that estrogens increase hepatic biosynthesis of TG. It remains to be determined whether this hormone also has selective effects on hepatic carrier apolipoprotein synthesis as re-

TABLE IV

Effects of Sex Steroid Treatment on Rat Adipose Tissue LPL Activity in Fed Animals

\begin{tabular}{lcccc}
\hline & \multicolumn{4}{c}{ Animal group* } \\
\cline { 2 - 5 } \multicolumn{1}{c}{ Parameters } & $\mathrm{C}(19)$ & $\mathrm{E}(22)$ & $\mathrm{P}(21)$ & $\mathrm{E}+\mathrm{P}(21)$ \\
\hline Tissue protein content, \% of wet tissue weight & $1.9 \pm 0.1$ & $1.8 \pm 0.1$ & $1.5 \pm 0.1 \S \|$ & $1.6 \pm 0.1 \S$ \\
LPL, $U \ddagger$ & & & & \\
per $m g$ protein & $73 \pm 9$ & $40 \pm 6 \S$ & $118 \pm 17 \S \|$ & $119 \pm 17 \S \|$ \\
per $\mu g$ g $N A$ & $2.5 \pm 0.4$ & $1.4 \pm 0.2 \S$ & $3.5 \pm 0.5 \S \|$ & $4.4 \pm 0.7 \S \|$ \\
per $g$ wet tissue & $287 \pm 55$ & $159 \pm 25 \S$ & $670 \pm 142 \S \|$ & $594 \pm 116 \S \| \mathbb{\|}$ \\
\hline
\end{tabular}

* Numbers in parentheses are the number of animals studied in each group.

$\ddagger 1 \mathrm{U}$ is defined as $1 \mathrm{nmol}$ glycerol released in $60 \mathrm{~min}$ at $37^{\circ} \mathrm{C}$.

$\S \| \uparrow$ Significance of the difference between group means \pm SEM : ( $\$$ ) control (C) vs. other groups, $P<0.05$;

(\|) E vs. $\mathrm{P}$ or $\mathrm{E}+\mathrm{P}, P 0.05$; (I) $\mathrm{P}$ vs. $\mathrm{E}+\mathrm{P}, P<0.001$. 
TABLE V

Effects of Sex Steroid Treatment on Rat Mammary Gland LPL Activity in Fed Animals

\begin{tabular}{lcccc}
\hline & \multicolumn{4}{c}{ Animal groups* } \\
\cline { 2 - 5 } \multicolumn{1}{c}{ Parameters } & $\mathrm{C}$ & $\mathrm{E}$ & $\mathrm{P}$ & $\mathrm{E}+\mathrm{P}$ \\
\hline Tissue protein contents, \% of wet tissue weight & $6 \pm 0.3$ & $7.7 \pm 0.4 \S$ & $5.7 \pm 0.4$ & $6.3 \pm 0.3$ \\
& & & & \\
LPL activity, $U \ddagger$ & & & & \\
per $m g$ protein & $2.2 \pm 0.6$ & $4.4 \pm 0.7 \S$ & $16.4 \pm 4.4 \S \|$ & $27.1 \pm 6.8 \S \|$ \\
per $m g$ D $N A$ & $24 \pm 8$ & $76 \pm 11$ & $194 \pm 57 \S \|$ & $430 \pm 110 \S \|$ \\
per $\mathrm{g}$ wet tissue & $38 \pm 9 \S$ & $163 \pm 30 \S$ & $386 \pm 124 \S$ & $763 \pm 229 \S \|$ \\
\hline
\end{tabular}

* There were 10 animals in each group.

$\ddagger 1 \mathrm{U}$ is defined as $1 \mathrm{nmol}$ glycerol released in $60 \mathrm{~min}$ at $37^{\circ} \mathrm{C}$.

$\S \|$ Significance of the difference between group means \pm SEM : (\$) control (C) vs. other group $P<0.01$;

(\|) E vs. $\mathrm{P}$ or $\mathrm{E}+\mathrm{P}, P<0.025$.

ported in other species (36) or suppressive action on intrahepatic lipolytic activity which would also contribute to these changes.

Another potential mechanism responsible for changes in plasma TG concentrations after sex steroid exposure is altered peripheral tissue removal. Plasma TG catabolism and subsequent tissue uptake of free fatty acid moieties are controlled by LPLs, a family of enzymes measurable in both plasma and tissues of mammalian species (37). Although various tissue and plasma lipolytic activities cannot be equated with rates of lipid removal directly, a strong inverse correlation between serum TG levels and activities of specific lipases would suggest a cause and effect relationship. Such a relationship was not found in all instances.

Adipose tissue is a rich source of LPL and a major site of TG removal from plasma $(37,38)$. E treatment was associated with the greatest elevations of this plasma lipid and was the only situation where increased TG entry and significant suppression of LPL were observed in both adipose tissue and liver (i.e., protamineresistant LPL) as well as in postheparin plasma. In the context of LPL, then, one might conclude that a defective removal mechanism contributed to the plasma lipid disturbance induced by estrogens. Mammary gland tissue responses must be separated from these findings, however, since its LPL activity increased during estrogen treatment, and it is not known to what extent this steroid modifies lipases in other tissues not examined in this study.

Other data do not support a major influence of LPL activity on plasma TGs with other treatment regimens. In the majority of instances $\mathrm{P}$ by itself or combined with $\mathrm{E}$ increased tissue LPL activity whereas plasma lipid was either unchanged or increased. Finally, calculations of correlation coefficients which assessed the statistical relationships between plasma TG and plasma PHLA or tissue LPL failed to reveal significance in most cases in contrast to a highly significant correlation between plasma levels and TG entry.

The differential effects of sex steroids on plasma PHLA and various tissue LPL activities might be explained in several different ways. First, conventional in vitro measurements of LPL activity are known to be modified by relative concentrations of both inhibitory and stimulatory cofactors derived from apo-VLDL (39). Some of the discrepancies between activities in plasma and tissues, then, may be caused by uncontrollable differences in levels of these cofactors in the plasma assay system. ${ }^{6}$

Differential actions of sex steroids on tissue LPL activities may also relate to indirect effects of estrogen or $\mathrm{P}$ on other hormones which may have an influence on specific tissue LPL activities. For example, increased

${ }^{6}$ In the presence of increasing amounts of serum from rats treated with $\mathrm{E}$ or $\mathrm{E}+\mathrm{P}$, adipose $\mathrm{LPL}$ activities are progressively suppressed (40).

TABLE VI

Correlation Coefficients Relating Plasma TG Concentrations to Other Parameters in Fed Rats

\begin{tabular}{|c|c|c|c|c|c|}
\hline \multirow[b]{2}{*}{ Parameters } & & \multicolumn{4}{|c|}{ Animal groups } \\
\hline & & C & $\mathbf{E}$ & $\mathbf{P}$ & $E+P$ \\
\hline TG entry & $\begin{array}{l}n^{*} \\
r\end{array}$ & $\begin{array}{l}10 \\
0.94 \S\end{array}$ & $\begin{array}{l}10 \\
0.87 \S\end{array}$ & $\begin{array}{l}10 \\
0.80 \S\end{array}$ & $\begin{array}{l}10 \\
0.78 \S\end{array}$ \\
\hline Adipose LPL & $\begin{array}{l}n \\
r\end{array}$ & $\begin{array}{l}18 \\
-0.57 \ddagger\end{array}$ & $\begin{array}{l}19 \\
0.18\end{array}$ & $\begin{array}{l}20 \\
-0.27\end{array}$ & $\begin{array}{c}18 \\
-0.50\end{array}$ \\
\hline PHLA & $\begin{array}{l}n \\
r\end{array}$ & $\begin{array}{l}10 \\
0.22\end{array}$ & $\begin{array}{l}10 \\
-0.25\end{array}$ & $\begin{array}{l}10 \\
0.05\end{array}$ & $\begin{array}{l}10 \\
-0.13\end{array}$ \\
\hline Protamine-resistant PHLA & $\begin{array}{l}n \\
r\end{array}$ & $\begin{array}{l}10 \\
0.13\end{array}$ & $\begin{array}{l}10 \\
0.02\end{array}$ & $\begin{array}{l}10 \\
0.16\end{array}$ & $\begin{array}{l}10 \\
0.32\end{array}$ \\
\hline Mammary gland LPL & $\begin{array}{l}n \\
r\end{array}$ & $\begin{array}{l}10 \\
0.30\end{array}$ & $\begin{array}{l}10 \\
0.52\end{array}$ & $\begin{array}{l}10 \\
0.72 \ddagger\end{array}$ & $\begin{array}{l}10 \\
0.56\end{array}$ \\
\hline
\end{tabular}

$* n=$ number of animals in each group.

$\ddagger \S$ Significant correlation at $5 \%$ level $(\ddagger)$ or $1 \%$ level $(\S)$. 
prolactin and growth hormone release or elevated plasma concentrations of free cortisol attend the administration of $E(41-43)$, whereas $P$ has suppressive effects on pituitary growth hormone release (44). Both steroids promote hyperinsulinemia in the rat (45). Most of these hormonal changes have been shown to influence hormone-sensitive lipases (46), and it is conceivable that they may also exert effects on LPL activity, since preliminary reports of prolactin-induced alterations of both adipose and mammary gland LPL activity have already appeared (47), and a similar action of insulin is well established (48).

Our assay system measured glycerol release as an index of LPL activity. It is also possible that accurate determinations of this enzyme may have been obscured by additional effects of these sex steroid regimens on mono- or diglyceride lipases known to be active under these assay conditions (49-51). However, actual measurements of these mono- and diglyceride lipases by other techniques (51) in this laboratory revealed that alterations of glycerol release by sex steroids could not be attributed to changes of activity of these enzymes as opposed to LPL (unpublished data).

There has been much emphasis on the role of hyperinsulinemia in the development of hypertriglyceridemia (52). More recently, actual TG entry in obese states has been related statistically to increased concentrations of plasma insulin (31). It is also known that plasma substrate alterations including glucose and increased free fatty acid flux to liver may also promote hypertriglyceridemia $(53,54)$. In the present study, however, the effects of three different hormonal regimens did not consistently change basal glucose or free fatty acid levels. All treatments did increase plasma concentrations of insulin to a comparable degree despite different effects on TG entry, plasma TG concentrations, and LPL. Moreover, $\mathrm{P}$ caused the greatest gains in body weight, attributed by others to increased carcass fat (55), but this regimen had little effect on plasma TG. These results suggest that the influence of $E$ or $P$ on TG metabolism is more dependent on the actual steroid administered than to changes in plasma glucose, free fatty acids, insulin, or body weight.

We conclude that LPL activities in plasma and certain selected tissues do not correlate uniformly with actual alterations of plasma levels of TG. Others have also reported normal or increased TG removal despite depressed plasma PHLA in women receiving estrogen alone or combined with progestins (14). Of the two parameters measured in our investigation, LPL and TG entry, the latter appeared to parallel changes in plasma TG most consistently. This also suggests that sex steroid influence on plasma TG may be expressed primarily by their actions on hepatic synthesis and release of this lipid.

\section{ACKNOWLEDGMENTS}

The authors express their appreciation to Mmes. Lois Muckerheide, Jacquelyn Marks, and Sabina Wajsbrot for their excellent technical assistance.

This study was supported by the U. S. Public Health Service Research grant AM-10305, by TOPS Club, Inc., Obesity and Metabolic Research Program, Milwaukee, Wisc., and by a grant from the Wisconsin Heart Association.

\section{REFERENCES}

1. Lorenz, F. W., I. L. Chaikoff, and C. Entenman. 1938. The endocrine control of lipid metabolism in the bird. II. The effects of estrin on the blood lipids of the immature domestic fowl. J. Biol. Chem. 126: 763-769.

2. Hillyard, L. A., C. Entenman, and I. L. Chaikoff. 1956. Concentration and composition of serum lipoproteins of cholesterol-fed and stilbestrol-injected birds. J. Biol. Chem. 223 : 359-368.

3. Boyd, E. M. 1934. The lipemia of pregnancy. J. Clin. Invest. 13: $347-363$.

4. Furman, R. H., P. Alaupovic, and R. P. Howard. 1967. Effects of androgens and estrogens on serum lipids and the composition and concentration of serum lipoproteins in normolipemic and hyperlipidemic states. Prog. Biochem. Pharmacol. 2: 215-249.

5. Glueck, C. J., W. V. Brown, R. I. Levy, H. Greten, and D. S. Fredrickson. 1969. Amelioration of hypertriglyceridaemia by progestational drugs in familial type-V hyperlipoproteinaemia. Lancet. I: 1290-1291.

6. Fabian, E., A. Stork, J. Kobilkova, and J. Sponarova. 1967. The activity of the lipoprotein lipase and estrogens. Enzymol. Biol. Clin. 8: 451-455.

7. Hazzard, W. R., M. J. Spiger, J. D. Bagdade, and E. L. Bierman. 1969. Studies on the mechanism of increased plasma triglyceride levels induced by oral contraceptives. N. Engl. J. Med. 280: 471-474.

8. Rossner, S., U. Larsson-Cohn, L. A. Carlson, and J. Boberg. 1971. Effects of an oral contraceptive agent on plasma lipids, plasma lipoproteins, the intravenous fat tolerance and the post-heparin lipoprotein lipase activity. Acta Med. Scand. 190: 301-305.

9. Hazzard, W. R., D. T. Notter, M. J. Spiger, and E. L. Bierman. 1972. Oral contraceptives and triglyceride transport: acquired heparin resistance as the mechanism for impaired post-heparin lipolytic activity. J. Clin. Endocrinol. Metab. 35: 425-437.

10. Kalkhoff, R., S. Bhatia, M. Matute, and H. Kim. 1973. Effects of sex steroids and pregnancy on hepatic lipid metabolism. Diabetes. 22 (Suppl. 1) : 321. (Abstr.)

11. Fewster, E., R. E. Pirrie, and D. A. Turner. 1967. Effect of estradiol benzoate on lipid metabolism in the rat. Endocrinology. 80: 263-271.

12. Kudzma, D. J., P. M. Hegstad, and R. E. Stoll. 1973. The chick as a laboratory model for the study of estrogen-induced hyperlipidemia. Metab. (Clin. Exp.). 22: 423-434.

13. Kekki, M., and E. A. Nikkila. 1971. Plasma triglyceride turnover during use of oral contraceptives. Metab. (Clin. Exp.). 20: 878-889.

14. Kissebah, A. H., P. Harrigan, and V. Wynn. 1973. Mechanism of hypertriglyceridaemia associated with 
contraceptive steroids. Horm. Metab. Res. 5: 184-190.

15. Otway, S., and D. S. Robinson. 1967. The use of nonionic detergent (Triton WR-1339) to determine rates of triglyceride entry into the circulation of the rat under different physiological conditions. J. Physiol. (Lond.). 190: 321-332.

16. Schurr, P. E., J. R. Schultz, and T. M. Parkinson. 1971. Triton-induced hyperlipemia in rats as an animal model for screening hypolipemic drugs. Lipids. 7: 68-74.

17. Wagner, H. N., Jr. 1968. Technical details of common procedures. In Principles of Nuclear Medicine. H. N. Wagner, Jr., editor. W. B. Saunders Company, Philadelphia. 833-858.

18. Korn, E. D. 1959. The assay of lipoprotein lipase in vivo and in vitro. Methods Biochem. Anal. 7: 145-192.

19. McBride, O. W., and E. D. Korn. 1963. The lipoprotein lipase of mammary gland and the correlation of its activity to lactation. J. Lipid Res. 4: 17-20.

20. Robinson, D. S. 1963. Changes in the lipolytic activity of the guinea pig mammary gland at parturition. $J$. Lipid. Res. 4 : 21-23.

21. Lowry, O. H., N. J. Rosebrough, A. L. Farr, and R. J. Randall. 1951. Protein measurement with the Folin phenol reagent. J. Biol. Chem. 193: 265-275.

22. Burton, K. 1956. A study of the conditions and mechanism of the diphenylamine reaction for the colorimetric estimation of deoxyribonucleic acid. Biochem. J. 62: 315-323.

23. Schotz, M. C., and A. S. Garfinkel. 1972. A simple lipase assay using trichloroacetic acid. J. Lipid Res. 13: 824-826.

24. Havel, R. J., H. A. Eder, and J. H. Bragdon. 1955. The distribution and chemical composition of ultracentrifugally separated lipoproteins in human serum. $J$. Clin. Invest. $34: 1345-1353$.

25. Scanu, A. M., and C. Edelstein. 1971. Solubility in aqueous solutions of ethanol of the small molecular weight polypeptides of the serum very low density and high density lipoproteins: relevance to the recovery problem during delipidation of serum lipoproteins. Anal. Biochem. 44: 576-588.

26. Fielding, C. J. 1970. Human lipoprotein lipase inhibition of activity by cholesterol. Biochim. Biophy's. Acta. 218: 221-226.

27. Itaya, K., and M. Ui. 1965. Colorimetric determination of free fatty acids in biological fluids. J. Lipid Res. 6: 16-20.

28. Van Handel, E., and D. B. Zilversmit. 1957. Micromethod for the direct determination of serum triglycerides. J. Lab. Clin. Med. 50: 152-157.

29. Morgan, C. R., and A. Lazarow. 1963. Immunoassay of insulin: two antibody system. Plasma insulin levels of normal subdiabetic and diabetic rats. Diabetes. 12: 115126.

30. Snedecor, G. W., and W. G. Cochran. 1967. Statistical Methods. Iowa State University Press, Ames, Iowa. 6th edition. 91-104, 172-177.

31. Robertson, R. P., D. J. Gavareski, J. D. Henderson, D. Porte, Jr., and E. L. Bierman. 1973 Accelerated triglyceride secretion. A metabolic consequence of obesity. J. Clin. Invest. 52: 1620-1626.

32. Riley, S. E., and D. S. Robinson. 1974. Studies on the assay of clearing factor lipase (Lipoprotein lipase) Biochim. Biophys. Acta. 369: 371-386.

33. Krauss, R. M., H. G. Windmueller, R. I. Levy, and D. S. Fredrickson. 1973. Selective measurement of two different triglyceride lipase activities in rat postheparin plasma. J. Lipid Res. 14: 286-295.

34. Svanborg, A., and O. Vikrot. 1966. The effect of estradiol and progesterone in plasma lipids in oophorectomized women. Acta Med. Scand. 179: 615-622.

35. Windmueller, H. G., and R. I. Levy. 1968. Production of $\beta$-lipoprotein by intestine in the rat. J. Biol. Chem. 243: 4878-4884.

36. Chan, L.. R. Jackson, B. O'Malley, A. Gotto, and A. Means. 1974. Estrogen induction of lipoprotein synthesis in the cockerel. Clin. Res. 22: 337A.

37. Robinson, D. S. 1970. The function of the plasma triglycerides in fatty acid transport. Compr. Biochem. 18: $51-116$.

38. Havel, R. J., and A. Goldfien. 1961. The role of the liver and of extrahepatic tissues in the transport and metabolism of fatty acids and triglycerides in the dog. J. Lipid Res. 2 : 389-395.

39. Havel, R. J., C. J. Fielding, T. Olivercrona, V. G. Shore, P. E. Fielding, and T. Egelrud. 1973. Cofactor activity of protein components of human very low density lipoproteins in the hydrolysis of triglycerides by lipoprotein lipase from different sources. Biochemistry. 12: 1828-1833.

40. Kim, H-J., and R. K. Kalkhoff. 1974. Sex steroid effects on lipoprotein lipase. Circulation. 50 (Suppl. III) : 266. (Abstr.)

41. Meites, J., K. H. Lu, W. Wuttke, C. W. Welsch, H. Nagasawa, and S. K. Quadri. 1972. Recent studies on functions and control of prolactin secretions in rats. Recent Prog. Horm. Res. 28: 471-526.

42. Spellacy, W. N., K. L. Carlson, and S. L. Schade. 1967. Human growth hormone levels in normal subjects receiving an oral contraceptive. J. Am. Med. Assoc. 202 : 451-454.

43. Pulkkinen, M. O., and A. Pekkarinen. 1967. The levels of 17-hydroxycorticosteroids in the plasma of users of oral contraceptives. Acta Endocrinol. Suppl. 119: 156. (Abstr. 140.)

44. Bhatia, S. K., D. Moore, and R. K. Kalkhoff. 1972. Progesterone suppression of the plasma growth hormone response. J. Clin. Endocrinol. Metab. 35: 364-369.

45. Costrini, N. V., and R. K. Kalkhoff. 1971. Relative effects of pregnancy, estradiol and progesterone on plasma insulin and pancreatic islet insulin secretion. J. Clin. Invest. 50: 992-999.

46. Fain, J. N., and R. Saperstein. 1970. The involvement of RNA synthesis and cyclic AMP in the activation of fat cell lipolysis by growth hormone and glucocorticoids. Horm. Metab. Res. 2(Suppl. 2) : 20-27.

47. Zinder, O., R. W. Turkington, G. C. Majunder, N. Kadohama, J. H. MacIndoe, and W. L. Frantz. 1973. Hormonal regulation of gene expression in mammary cells. Recent Prog. Horm. Res. 29: 417-455.

48. Jungas, R. L., and E. G. Ball. 1963. Studies on the metabolism of adipose tissue. XII. The effects of insulin and epinephrine on free fatty acid and glycerol production in the presence and absence of glucose. Biochemistry. 2: 383-388.

49. Biale, Y., E. Gorin, and E. Shafrir. 1968. Characterization of tissue lipolytic and esterolytic activities cleaving full and partial glycerides. Biochim. Biophys. Acta. 152: 28-39.

50. Biale, Y., and E. Shafrir. 1969. Lipolytic activity toward tri- and monoglycerides in postheparin plasma. Clin. Chim. Acta. 23: 413-419. 
51. Greten, H. 1972. Enzymatic degradation of plasma lipoproteins. Exp. Annu. Biochim. Med. 31: 160-168.

52. Reaven, G. M., R. L. Lerner, and M. P. Stern. 1967. Role of insulin in endogenous hypertriglyceridemia. J. Clin. Invest. 46: 1756-1767.

53. Ford, S., Jr., R. C. Bozian, and H. C. Knowles, Jr. 1968. Interactions of obesity and glucose and insulin levels in hypertriglyceridemia. Am. J. Clin. Nutr. 21: 904-910.
54. Eaton, P., D. Steinberg, and M. Berman. 1965. Quantitative evaluation of free fatty acid and glyceride fatty acid metabolism in man. J. Clin. Invest. 44: 1042a. (Abstr.)

55. Galletti, F., and A. Klopper. 1964. The effect of progesterone in the quantity and distribution of body fat in the female rat. Acta Endocrinol. 46: 379-386. 